University of Nebraska - Lincoln

DigitalCommons@University of Nebraska - Lincoln

Faculty Publications: Department of

Entomology

Entomology, Department of

2021

\title{
Challenges for Adoption of Integrated Pest Management (IPM): The Soybean Example
}

\author{
A. F. Bueno \\ Empresa Brasileira de Pesquisa Agropecuária - Embrapa Soja, adeney.bueno@embrapa.br
}

A. R. Panizzi

Empresa Brasileira de Pesquisa Agropecuária - Embrapa Trigo

Thomas E. Hunt

University of Nebraska-Lincoln, thunt2@unl.edu

P. M. Dourado

Bayer Crop Science - São Paulo

R. M. Pitta

Empresa Brasileira de Pesquisa Agropecuária - Embrapa Agrossilvipastoril,

See next page for additional authors

Follow this and additional works at: https://digitalcommons.unl.edu/entomologyfacpub

Part of the Entomology Commons

Bueno, A. F.; Panizzi, A. R.; Hunt, Thomas E.; Dourado, P. M.; Pitta, R. M.; and Gonçalves, J., "Challenges for Adoption of Integrated Pest Management (IPM): The Soybean Example" (2021). Faculty Publications:

Department of Entomology. 959.

https://digitalcommons.unl.edu/entomologyfacpub/959

This Article is brought to you for free and open access by the Entomology, Department of at DigitalCommons@University of Nebraska - Lincoln. It has been accepted for inclusion in Faculty Publications: Department of Entomology by an authorized administrator of DigitalCommons@University of Nebraska - Lincoln. 


\section{Authors}

A. F. Bueno, A. R. Panizzi, Thomas E. Hunt, P. M. Dourado, R. M. Pitta, and J. Gonçalves 


\title{
Challenges for Adoption of Integrated Pest Management (IPM): The Soybean Example
}

\author{
A. F. Bueno, ${ }^{1}$ A. R. Panizzi, ${ }^{2}$ T. E. Hunt, ${ }^{3}$ \\ P. M. Dourado, ${ }^{4}$ R. M. Pitta, ${ }^{5}$ and J. Gonçalves ${ }^{6}$ \\ 1 Empresa Brasileira de Pesquisa Agropecuária - Embrapa Soja, Londrina, \\ Paraná, Brasil \\ 2 Empresa Brasileira de Pesquisa Agropecuária - Embrapa Trigo, Passo Fundo, \\ Rio Grande do Sul, Brasil \\ 3 University of Nebraska-Lincoln, Lincoln, NE, USA \\ 4 Bayer Crop Science - São Paulo, São Paulo, Brasil \\ 5 Empresa Brasileira de Pesquisa Agropecuária - Embrapa Agrossilvipastoril, \\ Sinop, Mato Grosso, Brasil \\ 6 Universidad Federal do Paraná, Curitiba, Paraná, Brasil \\ Correspondence - A. F. Bueno, Empresa Brasileira de Pesquisa Agropecuária - Embrapa \\ Soja, Caixa Postal 231, Londrina, Paraná, 86001-979, Brasil; \\ adeney.bueno@embrapa.br
}

\begin{abstract}
Soybean is considered one of today's most important crops. Planted on millions of hectares worldwide, the management of soybean pests usually requires large amounts of chemicals. However, a key component to meet the increasing demand for food due to the rapidly growing global population is protecting crops from pests while maintaining environmental quality through ecologically and economically sound integrated pest management (IPM) practices. Not only can IPM result in more profitable agriculture due to the reduction of pest control costs but also assures equitable, secure, sufficient, and stable flows of both food and ecosystem services. Despite those ecological and economic benefits, the vast areas of cultivated soybean
\end{abstract}

Published in Neotropical Entomology 50 (2021), pp 5-20

doi:10.1007/s13744-020-00792-9

Copyright (C) 2020 Sociedade Entomológica do Brasil. Published by Springer.

Used by permission.

Submitted 18 February 2020; accepted 3 June 2020; published 31 July 2020. 
as well as the convenience of spraying insecticides are encouraging the adoption of prophylactic pest control as a relatively inexpensive safeguard compared to IPM practices. Thus, in this forum, we discuss the reasons for soybean IPM not reaching its potential. We give examples of how we can revive this once successful pest management program with a focus on experiences in Brazil and the USA. We analyze IPM case studies to illustrate the need for growers to have easy and fast access to IPM information on its medium- and long-term benefits. Overall, this forum highlights the importance of IPM for agricultural sustainability including ecological and financial benefits.

Keywords: sustainability, insecticides, economic thresholds, crop management, food security

\section{Historical Background of Soybean Integrated Pest Management}

The global concept of integrated pest management (IPM) was established in the late 1950s. It is based on the idea that cultivated plants can tolerate certain levels of injury without economically relevant yield losses (Higley \& Peterson 1996). Stern et al (1959) defined the economic injury level (EIL) as the lowest pest density that can cause economic damage to plants. However, to avoid economic losses, pest management is usually applied before the EIL is reached. Thus, the appropriate time to initiate management to prevent a pest population from reaching the EIL was defined as the economic threshold (ET) (Pedigo et al 1986). According to this concept, pest management would only be appropriate when the pest population is equal to or greater than the ET, or is expected to surpass this level within hours or days. Action must be taken when ET is reached, not because that density represents an economic loss, but rather because it provides a treatment window to take action before pest density or injury increases enough to produce an economic loss (Peterson \& Higley 2002). Therefore, the ET is often set 50 to $80 \%$ lower than the EIL, giving farmers the confidence to adopt such ETs with negligible risks of economic yield loss. The development and use of ETs in association with simple and efficient pest sampling methods have been among the most important components for the advancement of pest science into what is now known as modern IPM (Higley \& Pedigo 1996). Modern IPM is crucial to a sustainable agriculture, avoiding the unnecessary use of synthetic pesticides. Not only does modern IPM include a rational use of pesticides through ET adoption, but it is also a harmonious combination 
of different pest management strategies, such as the use of resistance crops, augmentative biological control (ABC), biotechnology, among others (Kogan 1998). Each of these strategies may provide a different level of pest management, but their additive effects can significantly reduce yield losses (Dara 2019).

In Brazil, soybean IPM was first adopted in the late 1960 s and early 1970s. At that time, soybean, Glycine max (L.) Merrill, became the major commodity in the country, expanding agricultural frontiers from the subtropics to the tropics. Today, soybean is the largest crop in Brazil, with close to 36 million of hectares. Land use can be intensive, with some fields cropped two or even three times per season, usually with soybean as the first crop in summer, followed by maize as the second crop in autumn/winter, and eventually wheat as the third crop. Together, soybean and maize account for more than $80 \%$ of the total cultivated area and $85 \%$ of the grain production in Brazil (Cattelan \& Dall'Agnol 2018).

As soybean production expanded over the years, there was a growing need to manage the newly established insect pests. Despite the large diversity of pest species that damage soybean, Lepidoptera and Heteroptera have always been the primary taxa and have required large investments by Brazilian farmers to protect yield. Hazardous broadspectrum chemicals (e.g., DDT, toxaphene, methyl parathion, methomyl) were used to control these pests. Initially, results were acceptable, but soon those chemicals showed their deleterious side effects, such as pest resurgence caused by their impact on natural enemies (parasites/ predators) (Panizzi et al 1977a). At that time, the concepts of IPM were just starting to become popular worldwide (Kogan 1998).

Locally, IPM concepts were quickly distributed and incorporated into soybean cultivation. Regional reports based on international concepts introduced by foreign researchers visiting Brazil were published, but with limited reach (Williams et al 1973, Turnipseed 1974). Greater impact on a national level was achieved by distribution of a bulletin that contained color photos of major pests and their natural enemies, which helped to popularize the IPM concepts. This process was led by entomologists at the National Soybean Research Center of Embrapa (Embrapa Soja) in collaboration with visiting scientists from the USA (Panizzi et al 1977b). In the same year, Kogan et al (1977) publicized the Brazilian IPM experience in the international arena. 
A more general and inclusive view of the history of soybean IPM in Brazil was provided by Panizzi (2013), who identified four major periods: (1) origins and early developments during the 1970s, (2) the Baculovirus era during the 1980s, (3) the egg parasitoid momentum in the 1990s, and (4) the decline in soybean IPM in the new millennium. These four periods elucidate (1) the onset and fast adoption of IPM programs by academia and growers with massive (ca. 50\%) reduction in the use of insecticides (Godoy et al 2015); (2) the biological control of the major defoliator pest, the velvet bean caterpillar, Anticarsia gemmatalis Hübner; (3) the appearance and increasing importance of the egg parasitoid Trissolcus basalis (Wollaston) for the management of the major stink bug pest, Nezara viridula (L.); and (4) the decline in reputation and use of IPM as the main tool in managing soybean pests.

The USA is also a major soybean producer, with 30 to 36 million hectares each year from 1997 to 2018 (USDA NASS 2018). Grown primarily in the eastern half of the country, over $80 \%$ is produced in 12 states in the north-central region of the country. In the USA, IPM has also been recognized to be important to environmentally sustainable agriculture for decades. First expressed in national policy in the 1970 s (Nixon 1972, Carter 1979), IPM is now institutionalized and supported by the federal government on national, regional, and state levels by measures such as research grant programs, information dissemination, and IPM training through local extension offices.

Steffey (2015) lists about 40 species or species complexes of arthropods as soybean pests in the USA, half of which are considered significant economic pests, the other half classified as occasional pests. Some can cause damage to germinating plants and seedlings starting early in the production cycle, with pests like the seedcorn maggot, Delia platura (Meigen) (Higley \& Hammond 1994) and the bean leaf beetle, Cerotoma trifurcata Förster (Hunt et al 1994). In late season, other pests become important, such as the stink bug complex (Pentatomidae) (Greene \& Davis 2015). Some economically damaging pest species are widely distributed across the country, other species are relatively localized, and some widely distributed pests are only of economic importance in some areas (Kogan \& Turnipseed 1987, Steffey 2015). Generally, there are more economically damaging soybean arthropod pest species and subsequent insecticide application in the southern than 
in the north and north-central United States (Way 1994, Hammond 2006), where most of the production takes place.

In the USA, soybean arthropod pest pressure was relatively low in the north-central region prior to the early 2000s, and consequently, insecticide use was low (USGS 2018). Before 2000, states in the northcentral region typically reported $<1 \%$ of their soybean acreage being treated with an insecticide (USDA NASS 2018), if any at all, and management was directed primarily at localized outbreaks of defoliating insects (Ragsdale et al 2011). For example, in 2000, < 0.1\% of the soybean acreage in the north-central region was treated for arthropod pests (USDA NASS 2018). In the early 2000s, things changed, primarily because of an introduced pest, the soybean aphid (Aphis glycines Matsumura) (Ragsdale et al 2011), but also because of improved pesticide seed treatment technology and changes in farmers' perceptions and agronomic realities, which seemingly "threw IPM out the window" for many other arthropod soybean pests.

Today, even though soybean is one of the most important crops in both countries and a great diversity of pest management tools is available, soybean growers still are somewhat reluctant to fully adopt soybean IPM. In both Brazil and the USA, IPM adoption is confronted with similar difficulties, which include the need for a faster and easier pest sampling procedures and the growers' fear of significant yield losses without spraying insecticides. Those difficulties will be further discussed in this forum as an attempt to encourage increased soybean IPM adoption worldwide to fundamentally improve soybean production by sustainability combining equitable, secure, sufficient, and stable flows of food with environmental preservation.

\section{Soybean IPM Importance for Crop Sustainability and Its Main Adoption Challenges}

Sustainable soybean production aims to neither impose harm to the environment or biodiversity, nor reduce the quality or economic value of soybean yield. This is probably the greatest modern challenge of the new age, considering a global population that will reach almost 10 billion by 2050 . Thus, there is increasing demand for food that needs to be sustainably produced. Among different options to fulfill this huge 
demand for food, soybean plays an important role as one of the major crops worldwide, accounting for more than half of the global demand for oil and vegetable protein (Oerke \& Dehne 2004, USDA 2020, Faostat 2019). Two of the world's largest soybean producers, the USA and Brazil, produced approximately 120 and 115 million metric tons, respectively, during the 2018/2019 crop season (USDA 2020; Conab 2019). However, these levels of production could be increased if damage by insect pests was mitigated (Oerke 2006). Therefore, in an attempt to reduce the negative consequences of pest outbreaks and to improve profits, soybean growers schedule frequent control of phytophagous arthropods on a calendar basis (Zalucki et al 2009), often taking advantage of herbicide or fungicide sprays by including an insecticide. This usually leads to an overuse of insecticides without considering the recommended threshold level (prophylactic control) (Song \& Swinton 2009). However, to maintain the medium- and longterm sustainability of this crop, a better alternative to this overuse of pesticides is urgently needed. As previously mentioned, soybean IPM aims not only to rationally use insecticides but also to harmoniously integrate different pest management strategies (Zalucki et al 2009, Bueno et al 2011).

Despite the benefits provided by IPM, this philosophy has not been adopted to the necessary extent (Corrêa-Ferreira et al 2010) during the last decade in Brazil or in the USA. Instead, insecticide application has been excessive (Bueno et al 2010), impairing the efficiency of native biological control agents (Carmo et al 2010, Song \& Swinton 2009, Meissle et al 2010). In addition, pest management strategies other than insecticide application have had negligible adoption. The situation has recently changed somewhat with the adoption of Bt soybean cultivars; however, the adoption of a single pest management strategy has only short-term effects. It is therefore crucial to discuss the reasons for not adopting well-developed IPM recommendations with the combination of multiple pest management strategies. Among various challenges for soybean IPM adoption, two stand out: (1) the growers' fear of significant yield loss without spraying insecticides and their resulting reservations and refusal to fully adopt ETs and (2) the substantial amount of work required for insect monitoring. 
First Challenge for Soybean IPM Adoption: Reservations About ETs

Reservations about the accuracy of recommended soybean ETs are pointed out by critics as one of the major soybean IPM weaknesses today (Bueno et al 2013). ETs for the most important pests (defoliators and stink bugs) in soybean were first determined in the 1970 in both Brazil and the USA. However, soybean cultivars and their production system have undergone dramatic changes since then. One of the most important changes was the development of new soybean cultivars with improved yields, different growth habits (determinate and indeterminate), and a lower leaf area index (LAI) (Zanon et al 2015).

Plants with lower LAI could hypothetically be less tolerant to defoliation. However, since the ET is defined as percentage of defoliation (e.g., 30\% defoliation during soybean vegetative stage and 15\% defoliation during soybean reproductive stage), plant tolerance to defoliation (\%) is not supposed to change since the amount of leaf area that could be lost is already a relation (\%) to plant LAI. In one of the more recent studies, Batistela et al (2012) proved that newer soybean cultivars, regardless of growth habit (determinate or indeterminate), can tolerate the actual ET (30\% in the vegetative state or $15 \%$ in the plant reproductive stage) without significant yield reduction.

Similarly, some soybean growers and field consultants claim that soybean cultivars of indeterminate growth habit would be less tolerant to stink bugs due to the prolonged presence of pods. It in fact does prolong the period in which stink bugs can cause damage, but there is no relation to plant tolerance itself (Bueno et al 2013). Bueno et al (2015) more recently compared the recommended ET (2 stink bugs per meter) with a reduced ET ( 0.5 stink bug per meter) and demonstrated that decreasing the ET increased the number of required insecticide applications, but did not increase yield, bean quality, or net income even with some newer soybean cultivars with different growth habits (determinate and indeterminate) and lower leaf area index (LAI).

Other common reservations among soybean growers include the following:

a) In areas with high rainfall, such as in Mato Grosso State, Brazil, precipitation exceeds $2000 \mathrm{~mm} /$ year (Marcuzzo et al 2011). In these areas, it is often difficult to wait for an ET to occur before 
initiating pest management because of the risk of extended periods of rainfall impeding the application of insecticides, although it is important to consider that rainfall may negatively affect insect populations by either physical control, changes in insect behavior, or by providing a favorable microclimate for entomopathogenic epizootics. For example, Varella et al (2015) recorded Spodoptera frugiperda (Smith) egg mortality in maize caused by rainfall and wind as high as $47 \%$. Similarly, Fuxa and Richter (1999) studied factors that influence the natural control of $A$. gemmatalis by entomopathogens in soybean. They concluded that Metarhizium rileyi (Farlow) depends on rainfall to trigger high mortality among the caterpillars;

b) EILs and ETs were defined in small plots (research trials), so they do not reflect field reality. However, such an argument is not appropriate because soybean defoliation tolerance is not affected by the size of the cultivated area;

c) The operating capacity of growers practicing IPM is more complex than for those that do not practice IPM and spray on a schedule because IPM requires spraying on demand as determined by scouting and ETs. Non-IPM growers scale their operational demand (e.g., the number of sprayer machines needed) by considering herbicide and fungicide sprayings and scheduled on a calendar basis. Thus, insecticides are sprayed together with herbicides or fungicides even when pest infestations are low. The growers' argument for adopting this strategy is that a sprayer may take days to spray the whole farm and may be unable to return to the first, or another field if a pest reaches the ET. This strategy might appear reasonable, as it reduces the operational demand for spraying and monitoring. However, it compromises the optimal timing of the pest control tool (insecticide) as well as encourages a disregard for ETs. Consequently, it increases the number of insecticide applications that impact the community of natural enemies, and intensifies the selection for pesticide resistance.

It is important to note that ETs can vary slightly across different countries; however, there is no agronomic reason to not adopt them (Panizzi et al 1977b, Panizzi 1980, Batistela et al 2012, Bueno et al 
2013, 2015). Indeed, an analysis of the benefits of long-term ET adoption re-emphasizes the importance of ETs. Long-term analysis can help to account for common problems such as the evolution of pest resistance to the most frequently used insecticides, the reduction of ecosystem services provided by pollinators, and other nontarget effects of the overuse of pesticides.

Second Challenge for Soybean IPM Adoption: the Need for Easy and Fast Sampling Procedures

Correct management decisions require reliable, accurate, and rapid assessment of the pest population density. If assessments are not carried out with precision and adequate frequency, a significant risk of mistaken management decisions exists, which could result in unnecessary insecticide application, or omitting application when necessary. For above-ground soybean pests, two assessment methods are most frequently used: (a) the drop cloth and (b) the sweep net.

The sweep net is by far the most widely used sampling tool to collect insects worldwide and has been the most important one for the past century. Early studies on the efficiency of the sweep net by De Long (1932) identified several environmental factors (temperature, humidity, wind speed, sun position, etc.) and plant characteristics (size, density, etc.) responsible for the great variability observed in sampling results. This might be in part responsible for the replacement of the sweep net by the drop cloth, which is more precise, and therefore frequently recommended in soybean today. Despite its efficacy for insecticide application purpose, soybean growers complain about the difficulties of its use because, among other issues, it requires qualified workers and is very time-consuming when sampling large areas.

As an attempt to facilitate insect sampling, promising results were obtained with the use of insect pheromones in baited traps. Several studies indicate attraction and capture of pests by traps containing synthetic insect sex pheromone compounds to be successful, particularly for Lepidoptera and Hemiptera species (Borges et al 1998, Pires et al 2000, Schmidt et al 2003). Although these results are quite promising, there is no simple correlation between the number of insects collected in the traps and the size of the pest population in the soybean field, limiting its use for ET decision-making. 
It is also possible to optimize the trap monitoring process by using sensors that perform insect counting. However, since the trap uses sex pheromones, only one species per trap would be monitored. Therefore, research is needed that develops imaging methods to identify captured species, combining texture, color, and shape parameters (Wen et al 2015), or by species-specific wing beat pattern (Potamitis et al 2015, Potamitis \& Rigakis 2015). In addition to monitoring moths, techniques that allow rapid monitoring of other pests such as mites and whiteflies would be extremely helpful.

Another promising insect sampling method is the use of aerial images (satellite or drone imagery). With cameras becoming more powerful and less expensive, this technology will become helpful for pest monitoring, as well as reducing time and cost associated with IPM. According to Nansen et al (2014), plants under abiotic or biotic stress have spectral behaviors that differ from healthy plants. Aphid-infested sorghum and soybean plants show reductions in near infrared reflectance (NIR) and normalized difference vegetation index (NDVI) (Alves et al 2015, Elliot et al 2015). However, research is still needed to make use of spectral readings for monitor soybean pests because of possible interactions between biotic and abiotic factors. For example, Board et al (2007) found a highly significant NDVI alteration in soybean plants submitted to high levels of defoliation, so work is required to differentiate the different causes of altered spectral readings.

Therefore, although the use of spectral imagery using onboard sensors on unmanned aerial vehicles (UAVs) or mounted on agricultural equipment (e.g., sprayers) can be a future tool that allows quick and systematic pest monitoring, further research is necessary concerning calibration, cause of signal differentiation, and other aerial image adjustments. At present, even with the development of new technologies, the most traditional sampling procedures (e.g., drop cloth, sweep net) are still necessary to deliver the required precision in insect monitoring and IPM decision-making. Regardless of technology used, high tech image acquisition, or old fashion sampling techniques, successful IPM is not possible without efficient pest population monitoring. 


\section{Soybean IPM Case Studies}

Soybean production in Brazil and the USA varies depending on region, climate, and other variables. In Brazil, soybean is cultivated in a variety of scenarios from family farming (small areas) to large companies (large areas). Most of the small farms are located in the Southern Region (Paraná, Santa Catarina, and Rio Grande do Sul). Most of the large areas are located either in the Midwest (Mato Grosso, Mato Grosso do Sul, Goiás, and the Federal District) or in the Northeast (Maranhão, Tocantins, Piauí, and Bahia) (Conab 2017).

In the USA, soybean farming is overwhelmingly characterized by family-held individual farms. In 2017, American soybean growers grew and harvested about 4.39 billion bushels of soybeans on farms across the USA, 97\% of which were family owned (USDA 2020). In this forum, we tried to analyze those different scenarios (small and large soybean fields) in both Brazil and the USA.

Small Farm Scenario: Results of Six Crop Seasons Adopting IPM in Parana State, Brazil

The rational use of insecticides can certainly be a part of soybean pest management and allow for grower profitability, reduce medium- and long-term pesticide risks to human health and the environment, and make soybean production overall safer and more sustainable. This is not only demonstrated through research, but is readily be observed in commercial fields in Parana State, Brazil, due to the joint IPM work carried out by the Parana Institute of Technical Assistance and Rural Extension (EMATER) and Embrapa Soja. The results of the first 5 years of the project show savings in insecticides use between $43.2 \%$ (2016/2017 season) and 55.9\% (2017/2018 season) in areas using IPM(Conte et al 2014, 2015, 2016, 2017, and 2018). A comparison among areas following IPM and areas without IPM(the Parana State average) is depicted in Table $\mathbf{1 .}$

In the sixth year of the project (2018/2019 crop season), results were separated for areas cultivated with Bt soybean and non-Bt soybean. A reduction of $48.8 \%$ in insecticide use due to the adoption of soybean IPM in non-Bt soybean areas and a reduction of 53.6\% in insecticides in Bt soybean areas were observed (Table 2) (Conte et al 
Table 1 Soybean IPM results (mean). Program carried out since 2013 in Parana State, South Brazil (adapted from Conte et al 2014, 2015, 2016, 2017, and 2018).

\begin{tabular}{|c|c|c|c|c|c|c|}
\hline Variable & Comparison & $\begin{array}{l}\text { Crop season } \\
2013 / 2014\end{array}$ & $2014 / 2015$ & $2015 / 2016$ & $2016 / 2017$ & $2017 / 2018$ \\
\hline \multirow{2}{*}{$\begin{array}{l}\text { Number of insecticide } \\
\text { sprayings over the } \\
\text { crop season }\end{array}$} & IPM & 2.3 (46 growers) & 2.1 (106 growers) & 2.1 (123 growers) & 2.0 (141 growers) & 1.5 (196 growers) \\
\hline & Non-IPM & 5.0 (333 growers) & 4.7 (330 growers) & 3.8 (314 growers) & 3.7 (390 growers) & 3.4 (615 growers) \\
\hline \multirow{2}{*}{$\begin{array}{l}\text { Days until first insecticide } \\
\text { spraying }\end{array}$} & IPM & 60 days & 66 days & 66.8 days & 70.8 days & 78.7 days \\
\hline & Non-IPM & 33 days & 34 days & 36 days & 40.5 days & 43.6 days \\
\hline \multirow{2}{*}{$\begin{array}{l}\text { Pest control costs } \\
\text { (bags of } 60 \mathrm{~kg} / \mathrm{ha} \text { ) }\end{array}$} & IPM & 2.41 & 2.00 & 2.00 & 2.30 & 1.41 \\
\hline & Non-IPM & 5.03 & 5.00 & 4.00 & 4.10 & 3.27 \\
\hline \multirow[t]{2}{*}{ Yield (bags of $60 \mathrm{~kg} / \mathrm{ha}$ ) } & IPM & 49.23 & 60.20 & 57.10 & 64.50 & 61.7 \\
\hline & Non-IPM & 48.67 & 58.60 & 54.70 & 64.20 & 60.4 \\
\hline
\end{tabular}

Program where public consultants (from EMATER-Paraná) sampled pests over the seasons and took all the decisions about pest management in IPM areas in selected farmers. At the end of the season, the results of IPM areas were compared with other non-IPM areas of Paraná, Brazil.

Table 2 Soybean IPM results (mean), Paraná State, Brazil (adapted from Conte et al 2019).

\begin{tabular}{|c|c|c|c|c|}
\hline \multirow[t]{2}{*}{ Variable } & \multirow[t]{2}{*}{ Comparison } & \multicolumn{3}{|c|}{ Crop season 2018/2019 } \\
\hline & & Non-Bt & Bt & Average \\
\hline \multirow{2}{*}{$\begin{array}{l}\text { Number of insecticide sprayings } \\
\text { over the crop season }\end{array}$} & IPM & 2.1 (113 growers) & 1.3 (128 growers) & 1.7 (241 growers) \\
\hline & Non-IPM & 4.1 & 2.8 & 3.4 (773 growers) \\
\hline \multirow[t]{2}{*}{ Days until first insecticide spraying } & IPM & 66.2 & 80.8 & 74.0 \\
\hline & Non-IPM & 38.7 & 48.7 & 40.3 \\
\hline \multirow[t]{2}{*}{ Pest control costs (bags of $60 \mathrm{~kg} / \mathrm{ha}$ ) } & IPM & 2.6 & 1.6 & 2.1 \\
\hline & Non-IPM & 5.0 & 3.4 & 4.1 \\
\hline \multirow[t]{2}{*}{ Yield (bags of 60 kg/ha) } & IPM & 50.9 & 49.5 & 50.1 \\
\hline & Non-IPM & 48.3 & 51.1 & 48.6 \\
\hline
\end{tabular}

2019). This reduction in insecticide use has saved the equivalent value of $120 \mathrm{~kg} / \mathrm{ha}$ in this crop season. This was only possible due to the adoption of ETs, which are the keystones to successful IPM. Soybean ETs are safe to adopt because the soybean plant is generally very tolerant to different types of insect injury. Results from studies carried out at Embrapa Soja (ongoing PhD thesis) illustrate this. In those studies, soybean plants, even with $15 \%$ of their pods damaged at the R4 stage (by perforation that triggers the loss of one bean per damaged 
Table 3 Soybean plant capacity of tolerating pod and flower injury (ongoing PhD thesis, unpublished data). Londrina, Parana State, Brazil (adapted from Bueno et al 2018).

\begin{tabular}{lllr} 
Crop season & Injury & Cultivar & $\mathrm{kg} / \mathrm{ha}$ \\
\hline 2016/2017 & $\begin{array}{l}\text { 15\% of injured pods in the R4 stage } \\
\text { Control without injury }\end{array}$ & BRS 388 RR & 7588.0 \\
& & & 7572.0 \\
2018/2019 & $\begin{array}{l}\text { 100\% of flower removal in the R2 stage } \\
\text { Control without injury }\end{array}$ & BRS 1001 IPRO & 2940.3 \\
& & 2856.3 \\
\hline
\end{tabular}

pod), or with $100 \%$ of the flowers manually removed at full bloom stage (R2), still had a similar yield as the uninjured control (Table 3) (Bueno et al 2018).

Overall, the great advantage of IPM is that lower insecticide use is possible without significant yield loss. Soybean growers that adopted IPM saved a value equivalent to between 1.8 (2016/2017 season) and three soybean bags (2014/2015 season) of $60 \mathrm{~kg} / \mathrm{ha} /$ year over the 6 years of the project. The adoption of soybean IPM reduced the overall use of insecticides and delayed the first insecticide application. On average, the first insecticide application was performed 33 to 43.6 days after soybean sowing in the state of Parana (Non-IPM); IPM adopters only applied insecticides 60 to 78.7 days after sowing (Table 1). Similarly, in the 2018/2019 crop season, growers that did not follow IPM made the first insecticide application 38.7 and 48.7 days after non-Bt and $\mathrm{Bt}$ soybean were sown, respectively (average for the state of Parana), while the first insecticide application by IPM adopters was performed 66.2 and 80.8 days after sowing of non-Bt and Bt soybean, respectively. This longer period without insecticides in the crop preserves natural biological control, which helps to prevent pest outbreaks. Moreover, in a balanced agroecosystem, an insecticide or any kind of pest management action does not need to achieve $100 \%$ pest mortality, as generally desired by most growers. Insecticides only need to reduce pest populations to a level below economic injury. Indeed, $100 \%$ control of a given pest could be undesirable, as it may lead to a decline of natural enemies due to the unavailability of prey or hosts, among other economic and environmental reasons (Bueno et al 2013, Dara 2019). Changing the growers' expectation of $100 \%$ control to one that accepts 
that pest management should simply reduce pest populations to noneconomically damaging levels is one of the most difficult but important challenges to achieve greater adoption and success of soybean IPM.

\section{Large Farm Scenario: Mato Grosso State, Brazil}

A public-private partnership between Embrapa and the Mato Grosso Grain Growers Association (APROSOJA-MT) enabled the installation of soybean IPM demonstration fields to gain growers' confidence in pest management practices (Huis \& Meerman 1997). In half of the fields, IPM was used, while the standard grower management (identify and spray strategy) was used in the other half. Each half consisted of at least 50 ha, since growers in Mato Grosso do not believe that smaller areas represent field reality.

It is important to note that the growers were responsible for sampling their fields because this helped them to better understand pest fluctuation as well as to verify the capacity of plants to tolerate injuries and replace damaged tissues throughout the season. After areas were harvested, the profitability of the pest management systems (IPM and standard producer management) was compared. In general, IPM areas produce the same yield as areas with conventional growers' management, but using approximately 50\% less insecticide. The results have been presented in lectures and media (television, radio, and internet). In addition, meetings were organized where growers had the opportunity to share their IPM experience with other growers, aiming to increase IPM adoption (Cumming \& Spiesman 2006).

In Brazil, an area-wide IPM adoption necessarily involves the expansion of training for extension personnel and investment by growers/consultants in hiring field scouts. Hiring a professional is usually considered an increase in production cost, but here this is not the case. To demonstrate that hiring a scouter is an investment, let us take the example of a property that grows 1000 ha of soybean. Considering that pest monitoring reduces the cost of insecticides for soybean fields in Mato Grosso State by at least US\$20/ha compared to insecticide application based on a schedule, that property saves a total of US\$20,00o. A field scout usually costs US\$15,000 per year (salary, benefits, and taxes), so there is a positive annual balance of US $\$ 5000$ 
in just one crop season. The positive balance can be even higher if we consider that in Brazil, two or even three crops per year are usually cultivated. Although in our example we used a property of 1000 ha, a field scout may be responsible for monitoring up to 2500 ha using the drop cloth for sampling. In addition, the cost of insecticide use may be higher than US\$20/ha. Considering all of this, the costs of schedulebased insecticide application will likely be higher than the expenses required for a field scout.

US Scenario: Mixed IPM Adoption in the Primary US Soybean Production Region

As noted above, the soybean aphid is by far the most economically damaging insect pest in the primary US soybean production region. The soybean aphid, native to eastern Asia, was first detected in 2000 in Wisconsin (Ragsdale et al 2004), a state in the north-central region of the country. The possible widespread economic impact of the pest was recognized, and the United States Department of Agriculture Cooperative State Research, Education, and Extension Service (USDA CSREES) released Critical Issues funding for the formation of a Rapid Response Multi-state Committee to facilitate a regional pest management effort directed at this insect (Nowierski \& Meyer 2008). The committee, NC- 502 Soybean Aphid: A New Pest of Soybean Production, was formed in September of 2000 and allowed collaborative research and extension teams to immediately initiate soybean aphid biology and ecology research as well as IPM tool development.

A robust seven state multiyear research project determined soybean aphid economic injury levels and economic thresholds (Ragsdale et al 2007), which were re-validated in 2016 considering changing economic conditions (e.g., crop price and management costs). The original enumerative sampling plan required whole-plant, aphid/plant counts and was cumbersome and time-consuming for in-field practitioners (e.g., farmers, field scouts, consultants), so a binomial sampling plan was developed that was much faster (reduced sampling from $1 \mathrm{~h}$ to $15 \mathrm{~min}$ ) (Hodgson et al 2004, Ragsdale et al 2011) and validated across several states (Hodgson et al 2007). Both hard copy speed scouting worksheets and electronic sampling tools (e.g., iPhone and Android apps, SoyPod DSS) were developed from the binomial sampling plan. 
In addition to these basic IPM tools, numerous studies addressed biological and ecological factors important for soybean aphid management and have been incorporated into soybean aphid IPM recommendations (Ragsdale et al 2011, Hodgson et al 2012, Koch et al 2016). For example, the generalist predator, Orius insidiosus (Say), can significantly decrease early season soybean aphid population growth in some regions (Desneux et al 2006, Brosius et al 2007). Further, a diverse landscape structure in a $1.5 \mathrm{~km}$ radius around a soybean field was found to positively effect soybean aphid biocontrol by natural enemies (Gardiner et al 2009). This information is used to reinforce the fact that applying insecticides too early or prophylactically can have negative effects. Information on the importance of natural enemies have been consistently included in soybean aphid IPM recommendations (e.g., Hodgson et al 2012).

Host plant resistance is another IPM tool for soybean aphid management. Antibiosis, antixenosis, and tolerance have been identified in several soybean varieties and plant introductions (e.g., Hill et al 2004, Diaz-Montano et al 2006, Hesler et al 2007, Pierson et al 2010). In 2010, seed companies released soybean aphid resistant soybean varieties (Ragsdale et al 2011). Unfortunately, soybean aphid biotypes have emerged that can survive on some current commercial soybean varieties with single-gene soybean aphid resistance (Kim et al 2008, Hill et al 2010). Clearly, a strategy is required to preserve, or at least prolong, the effectiveness of host plant resistance as an IPM tool as new soybean aphid resistant varieties are released to the farmers.

Region-wide outbreaks of soybean aphid (e.g., in 2005) resulted in millions of acres being treated with insecticides, up to $57 \%$ of the soybean acreage in some states (USDA NASS 2018). From 2000 to 2006, there was a 130-fold increase in insecticide use on soybean, likely due to the soybean aphid (Ragsdale et al 2011). Insecticide use on soybean further increased until 2014 but has since decreased (USGS 2018). This is in part because soybean aphid outbreaks are less common than during the 2000s (Bahlai et al 2015), but also because soybean prices have been low, and farmers respond by being more parsimonious with expenses. Regardless, it also begs the question "Is soybean aphid IPM being practiced and is it effective?"

The soybean aphid economic threshold is widely accepted and is generally believed to be high enough so that natural enemies have a 
chance to hold down, or at least slow down soybean aphid population growth (Ragsdale et al 2011). As noted above, conservation of natural enemies is promoted, and soybean aphid resistant soybean varieties are being planted. Before the introduction of the soybean aphid, $\leq 2 \%$ of the north-central region soybean acres were scouted for arthropod pests, but 10 years later, $77 \%$ of the soybean acres were regularly scouted (Song \& Swinton 2009). In a series of surveys conducted in the north-central region between 2004 and 2007, 84-94\% of the farmers reported that field scouting reports were very important to making soybean aphid management decisions. Over $70 \%$ of the farmers indicated that the frequency of soybean aphid insecticide treatment for profitable control depends on aphid counts, weather conditions, and plant growth stage. Over $80 \%$ of the farmers said that soybean aphids could repopulate insecticide treated fields during the same crop year. Although this is a good example of successful IPM use, it is at a basic level, targeting one pest and relying simply on using the basic tools of IPM (Kogan 1998, Peterson et al 2018). Whatever success may be claimed for soybean aphid IPM, it is tempered by concurrent practices that undermine this success and that are antithetical to IPM in general. These include the widespread use of insecticide seed treatments and prophylactic early to mid-crop season insecticide use in tank-mixes with herbicides, most often glyphosate.

The rapid increase in the use of insecticide seed treatments in soybean began in 2006 , rising to about 34 to $44 \%$ of soybean acreage by 2011 (Douglas \& Tooker 2015). The most common compounds applied as seed treatments (i.e., seed coatings) are neonicotinoids (imidacloprid, thiamethoxam, and clothianidin) (Elbert et al 2008). Current projections indicate that neonicotinoid seed treatment use in soybean will exceed 50\% (Mourtzinis et al 2019). Some studies have identified region-wide benefits of neonicotinoid seed treatments (e.g., Hurley \& Mitchell 2017), but others find the benefits negligible and variable (e.g., Gaspar et al 2014, Mourtzinis et al 2019). This seems likely because neonicotinoid seed treatments are only effective for very early season insect pests, which are of relatively low risk in any given year or location (Hesler et al 2018, Papiernik et al 2018). Furthermore, a survey of land-grant university websites across the north-central region finds a suite of IPM strategies to manage many of these arthropods. 
Bean leaf beetle, Cerotoma trifurcata (Forster), management serves as an example of IPM being supplanted by new technology, in this case, seed treatment. Bean leaf beetle is found across the north-central region, was the major yield limiting pest prior to the soybean aphid (Steffey 2015), and is the primary reason for neonicotinoid seed treatment in soybean. However, it is a significant soybean seedling pest only in early-planted, temporarily isolated soybean fields, and information on bean leaf beetle IPM tools and strategies (e.g., economic injury levels and thresholds, planting date, trap cropping) are widely available for early season occurrence on seedling soybean (e.g., Hunt et al 1995, Witkowski and Echtenkamp 1996) through late season management of pod feeding (e.g., Smelser \& Pedigo 1992, Hesler et al 2018). Bean pod mottle virus (BPMV), a bean leaf beetle vectored disease found primarily in the southern US, began to increase in incidence in the north central US (Giesler et al 2002), so bean leaf beetle management became a part of BPMV management in the north central region (Giesler et al 2002, Buyung et al 2012). Therefore, although bean leaf beetle IPM information and tools exist to manage this sporadic, albeit widespread pest, pressures of managing the pest and BPMV coupled with the ease of using an insecticide seed treatment have led to much reduced bean leaf beetle IPM in favor of widespread use of neonicotinoid seed treatments. Currently, bean leaf beetles are seldom observed at economically damaging levels, presumably because of this widespread use of seed treatments. However, because most seed treatments used on soybean to date are neonicotinoids (Elbert et al 2008), bean leaf beetle resistance to this class of insecticides is a concern.

The prophylactic use of seed treatments against arthropod pests for which IPM tools exist is contrary to IPM principles. It has been suggested that widespread neonicotinoid seed treatment may affect early season colonization of soybean aphid near their major overwintering locations (Bahlai et al 2015), but is not efficient for typical mid-season soybean aphid management (Krupke et al 2017). However, a robust set of IPM tools does exist for soybean aphid management.

The other relatively common practice antithetical to IPM is insecticide application at the time of herbicide application, often referred to as an "insurance" application, or an application to "clean-up" the field. This practice increased in frequency as glyphosate became the 
primary in-season herbicide used on glyphosate resistant soybean and in recent years is carried out together with mid-season fungicide application. Statistics on the frequency of this practice are not readily available, but commercial pesticide applicators often offer the addition of a low-cost insecticide as a "tank-mix" with their regularly scheduled herbicide or fungicide application. Although this practice can be effective and economical if a specific pest threshold is met, it is typically conducted without prior scouting or formal evaluation of the field with respect to arthropod pests.

The use of seed treatments, tank-mixing insecticides with herbicides or fungicides, and other "non-IPM" practices can be driven by a variety of causes. Farmer's often have an elevated perception of risk resulting from a past pest outbreak, spurious marketing, and other factors. A recent concept fostering insecticide application is that any potential stress (e.g., insects) poses a risk to "plant health" (Sappington 2014, Hurley \& Mitchell 2017). "Plant health" is a vague term, but the idea is to manage inputs to maximize plant health, thereby protecting and/or maximizing yield. Farmers who consider the improvement of plant health to be very important tend to use more insecticide treated seeds (Hurley \& Mitchell 2017). Plant health fits well with a marketing narrative, and because many farmers receive a significant portion of their pest management information from seed or chemical company representatives and agricultural retailers (Sappington 2014, Hurley \& Mitchell 2017), protecting plant health from arthropod pests is a major cause of their concern.

Implementation of effective IPM can be time-consuming and is complex and knowledge-dependent (e.g., Castle \& Naranjo 2009, Sappington 2014, Ehler 2006). Even managing the primary north-central region soybean arthropod pest, the soybean aphid, can be time-consuming and somewhat daunting to the average farmer, let alone organizing the information necessary to manage several other possible pests and other farming operations (e.g., fertilization, weed management) within an entire farming enterprise. This can be alleviated to some extent by employing crop consultants (Sappington 2014), who are more inclined to scout and use thresholds. However, consultants are also constrained by time, and many are not independent of agricultural retailers and service providers and therefore often have a conflict of interest (Ehler 2006). 
The introduction of transgenic crops (e.g., herbicide-resistant soybeans, insect-resistant maize), coupled with increasing farm size, further drives growers to look for ways to simplify their operations (e.g., Ehler 2006, Green \& Owen 2011, Sappington 2014). Although recent cases of glyphosate resistance and insect resistance to Bt proteins have complicated both weed and arthropod management in transgenic crops, over the years, farmers have become used to the relative ease with which pests were managed in these crops, and have come to expect this for other pest management.

There are other agricultural practicalities specific to soybean that have become an impediment to the use of certain IPM tools and strategies in the north-central region. In some cases, our IPM recommendations are not suitable to current soybean production practice. Except for one state in the north-central region, about 30 to $90 \%$ of the soybean acreage is planted in rows spaced $\leq 38.1 \mathrm{~cm}$ apart (USDA NASS 2018). Many of our economic and action thresholds are based on sweep net samples or pest/ft. of row counts obtained via drop cloth. Soybeans cannot be effectively sampled using these methods during the mid-late cropping season in fields with narrow rows, particularly in a well-developed canopy. One of our common recommendations for managing early season bean leaf beetle is delayed planting. However, research indicates that delayed planting leads to significant yield reduction for each day of delay past May 1 (17 kg ha $\mathrm{kay}^{-1}$ to $43 \mathrm{~kg} \mathrm{ha}^{-1}$ day $^{-1}$ ) (Bastidas et al 2008). Clearly, if we expect farmers to use our recommendations, we must continually update them to accommodate for current farming practicalities.

As noted at the outset of this discussion, another impediment to IPM adoption is the farmers' doubts and refusal to fully adopt ETs. We should acknowledge that there are economic, biological, and agronomic uncertainties associated the EILs and ETs (e.g., fluctuating crop values, inherent biological variability, variable insecticide efficacy), but also provide the farmer a means to understand and mitigate these uncertainties. One such attempt to incorporate the risk associated with variability was the probabilistic economic injury level (PEIL) (Peterson \& Hunt 2003). For example, Monte Carlo simulation was used to incorporate uncertainty associated with input variables used in EIL calculation for bean leaf beetle on seedling soybean. The resultant PEIL table presented a risk level associated with different 
PEILs. For example, a PEIL of 6.1 beetles/plant has a 5\% risk that the actual EIL would be lower, and a PEIL of 6.6 beetles/plant has a $10 \%$ risk that the actual EIL would be lower. The intent was for university extension specialists to convert the PEILs to ETs. A farmer could then select an ET based on the level of risk with which they were comfortable.

Why was some level of success achieved with the adoption of soybean aphid IPM tools while the adoption of IPM tools for other arthropod pests is less successful or moderate at best? An important component to soybean aphid IPM was "stakeholder integration." That is, farmers (i.e., stakeholders) were involved in almost all aspects of soybean aphid IPM development, even from the initial funding of research projects. The North Central Soybean Research Program (NCSRP) and State Soybean Boards funded much of the research and extension projects addressing the soybean aphid. The NCSRP and the State Soybean Boards are made up of farmers elected by other farmers, and the funds they dispense are "check-off" dollars. For example, each year in Nebraska $0.5 \%$ of the total selling price of the farmer's soybean grain goes to the Nebraska Soybean Board (NSB) ( https:// nebraskasoybeans.org ), which is led by nine farmers elected by $\mathrm{Ne}-$ braskan farmers. The NCB uses half of those funds to support soybean research, education, and marketing. The other half of the funds go to the national check-off, the United Soybean Board, which also supports soybean research and is led by farmers (https://www.unitedsoybean. org/ ). In addition, the NSB sends funds to the NCSRP (https://www. ncsrp.com/ ), another farmer led program that funds multi-state university soybean research and extension projects. Thus, farmers directly funded many of the soybean aphid IPM projects and were kept informed by quarterly/yearly reports. In many cases, they provided land for research projects, and finally, the farmer led NCSRP and State Soybean Boards helped promote the resulting IPM products. The more the farmers are involved, the more they accept and adopt researchbased IPM recommendations.

Although the soybean aphid has been by far the most economically damaging soybean insect pest in the primary US soybean production region during the last 20 years, the stink bug complex is a growing concern and the most recent target of collaborative IPM tool and strategy development. Stink bugs have been a common problem in the 
southern and mid-Atlantic regions of the USA, and both invasive and endemic species are becoming economically damaging pests in the north central US (Koch et al 2017). Because environmental and agronomic condition in the north central region differs from the south and mid-Atlantic regions, new or at least modified IPM tools and strategies are needed. As with the soybean aphid, the development of stink bug on soybean IPM is being done by multi-state, multi-disciplinary teams supported by the NCSRP and state commodity boards. To date, this team has generated region-wide information on basic stink bug community composition and temporal dynamics (Pezzini et al 2019a), sequential sampling (Pezzini et al 2019b), and stink bug parasitism (Anderson et al 2020), has begun to develop the resultant extension materials, and is currently conducting economic EIL research.

If we truly wish to achieve more agroecosystem-based IPM to manage pests and avoid plant stress across the agricultural system (Peterson et al 2018), we must also change our education efforts. Most IPM education is delivered by discipline, entomology, plant pathology, and weed science (Ehler 2006, Sappington 2014). How can we expect farmers to integrate IPM across a farming operation if we continue to compartmentalize the information we deliver? In the end, implementation of IPM is up to the farmer, so we must develop tools, information platforms, and educational programs best suited for the farmer or farm manager.

\section{Soybean IPM in the New Era: Biotechnology}

Foundation for Sustainable Systems Commercially available in Brazil since the 2013/2014 crop season, genetically modified soybean technology confers resistance against some important Lepidoptera pests and has been incorporated as a key tool within soybean IPM. The combination of the events MON $87701 \times$ MON 89788 expressing the Cry1Ac insecticide Bt protein against target pests, and the 5-enolpyruvylshikimate-3-phosphate synthase (EPSP) protein of Agrobacterium sp., which confers tolerance to glyphosate, commercially called Intacta RR2 $\mathrm{PRO} \cap$, provides protection against damage from major soybean pests. Nearly 24 million hectares were sown with Intacta RR2 PRO ${ }^{\circ}$ during the $2017 / 2018$ crop season, representing $41 \%$ of the 
total soybean acreage in Brazil, Argentina, Paraguay, and Uruguay. During this period, the total soybean acreage only in Brazil went from 30.17 million hectares to 35.15 million hectares, an increase of $16,5 \%$ (CONAB 2019). In 2013, over 1 million hectares were cultivated using biotechnology (Bt), increasing to over 23 million hectares in 2018, which is the equivalent to about $63 \%$ of the total area and evidence that Brazilian growers are aware of the benefits of this technology. The rapid technology adoption is primarily attributed to an average yield increase of $9.2 \%$ since $2013 / 2014$, efficient and simple weed management, and high efficacy against major lepidopteran soybean pests including Chrysodeixis includens: (Walker) A. gemmatalis, and Helicoverpa armigera: (Heliar) (Bernardi et al 2012, Bernardi et al 2014, Yano et al 2016, Dourado et al 2016).

Among the benefits of Bt soybean, area-wide pest suppression which benefits Bt as well as non-Bt soybeans stands out. Similar benefits were reported for Bt maize in the USA and Bt cotton in China and the USA, where consistent reduction of target pest populations and damage was observed in both Bt and non-Bt crops (Carrière et al 2003, Dively et al 2018, Hutchison et al 2010, Wan et al 2012, Wu et al 2008, Zhang et al 2018). The reduction in insecticide use provides an opportunity to promote the benefits of implementing soybean IPM, taking advantage of the selective activity of Bt toxins, and to maintain a more favorable environment for beneficial insects, including natural enemies (Romeis et al 2018). There are many widely accepted benefits of using Bt crops for insect pest management, including the reduced use of less effective and/or less environmentally friendly insecticides, high specificity toward pests, and a more convenient insect pest management strategy (Brookes \& Barfoot 2013, 2016). Despite the importance of Brazilian soybean production, there is little research designed to understand the landscape scale effects of Bt technology on the dynamics of non-target organisms, particularly predators and parasites that utilize Bt crops.

However, pest management can be more robust by complementing and including Bt technologies with other management tactics within the framework of soybean IPM, rather than treating Bt technology as a stand-alone insect management tactic. In this way, greatest potential to contribute significantly to the establishment of sustainable crop protection systems could be achieved (Romeis et al 2008). As 
mentioned earlier, Bt soybean technology has high specificity to manage target Lepidoptera species, so still demands regular field monitoring. The thresholds and tactics established during the 1970s should continue to be used to protect the crop from a range of non-target species, like Spodoptera spp., stink bugs, and a complex of secondary pests that can occasionally cause damage and yield loss. Random use of nonselective insecticides to manage non-target species of Bt soybean could eliminate natural enemies, resulting in pest outbreaks, economic loss, and loss of environmental benefits associated with $\mathrm{Bt}$ soybean adoption. In addition, when any primary pest is significantly reduced or eliminated by a technology such as Bt crops, it is possible that replacement inputs or other ecological factors will result in a pest shift that may require additional crop protection inputs. If those additional inputs are selective, the overall gains made by growers may still be very positive and IPM is consolidated (Naranjo \& Ellsworth 2009a, 2009b, Ellsworth et al 2017).

The evolution of insect resistance is the main challenge of Bt crop use. Brazilian growers have already been confronted with field-evolved resistance of $S$. frugiperda resulting from high adoption of Bt maize associated with poor refuge compliance and Bt maize that was not "high dose," a requirement of the "high dose" concept. Specifically, S. frugiperda evolved resistance to the Cry1F protein expressed in TC1507 maize (Farias et al 2014), and to the Cry1Ab expressed in MON 810 maize (Omoto et al 2016). Planting refuges of non-Bt crops has been the primary tactic used to delay resistance evolution to Bt crops (Carrière et al 2016). Intacta RR2 PRO $R$ expresses Cry1Ac to manage $C$. includens, $A$. gemmatalis, and $H$. armigera, which fits within the "high-dose/refuge" insect resistance management (IRM) strategy (Bernardi et al 2012, Bernardi et al 2014, Yano et al 2015, Dourado et al 2016). However, the success of IRM strategies proposed for Intacta RR2 PROR soybean continues to be highly dependent on the engagement of Brazilian stakeholders in the soybean production chain to deploy joint strategies and attain effective IRM compliance (e.g., planting of refuge). This new agricultural era using transgenic crops, in this case Bt soybean, is highly favorable and dependent on IPM adoption to succeed. It is important to emphasize that the adoption of the refuge area to delay insect resistance will not be sustainable without high IPM adoption. Refuge areas require IPM because they also need 
to produce the insects susceptible to the Bt technology, which will not occur if they are managed with an extensive use of insecticides. That is why today the IPM technology has been revived and gained a favorable reception among growers, consultants, and even pesticide dealers for more sustainable pest management.

\section{Concluding Remarks}

Despite the importance and success of soybean IPM which is discussed in this forum, worldwide adoption of soybean IPM is still not increasing as fast as it should. This is most likely due to a focus on the shortterm benefits of insecticide use, which includes low cost, simplicity of use, and an acceptable solution to the pest problem in soybean (at least short-term). Given a worldwide shrinking rural population combined with the increased demand for food, it is easy to understand the temptation for the short-term advantages of pesticide use and plant-incorporated protectants as inexpensive insurance to maintain soybean production profitability. Indeed, over the past 20 years, the overwhelming success of adopting prophylactic pest control tactics, transgenic crops (Bt technology), and seed treatments has challenged IPM (Peterson et al 2018). Nevertheless, mechanization is becoming more inexpensive, so more machinery is available for field work, which reduces the required labor and in turn allows IPM workers to be more productive and IPM successful.

Acceptance and implementation of IPM depends upon the interaction of numerous variables including the growers' and consumers' level of education and moral values, economic and social conditions, regulation, government policies, availability of IPM tools, extension education, consumer preference, and retail marketing, among other factors (Dara 2019). To foster IPM adoption in soybean or other crops, all of the pertinent variables, not just one or a few, need to be addressed, which will result in better outcomes from their combination. Furthermore, some IPM recommendations may not be practical and appropriate for all scenarios. Farmers and IPM professionals need to able to choose the best option(s) for their situation (Dara 2019). Investments in training and technology transfer should be made so technical assistance can reach the field level. 
Public-private partnerships in rural consultancy may be a way to overcome the lack of technical assistance that reaches the field (Krell et al 2016). Public or private technical assistance or rural extension combined with research and education is important for any IPM program to succeed (Nowierski \& Meyer 2008). Huffman and Evenson (2006) in reviewing the literature on the synergistic effects of cooperation between researchers and rural extensionists reported a return of up to $110 \%$ of public resources. Also, efficient communication between researchers, extension professionals, and growers is needed to intensify information dissemination (Bajwa et al 2003) in such a way that extension professionals pass on research-generated information to growers and forward the growers' feedback to researchers. According to Wang et al (2012), the increase in investments in rural extension (greater number of extension professionals) allows the intensification of benefits promoted by research, such as the reduction of production costs, among other benefits. However, there is a worldwide trend to reduce public rural extension. For example, Wang (2014) describes that the US government has been reducing its public investments in rural extension. A similar trend is observed in Brazil, which results in a reduction of knowledge involving the growers' fear of yield loss due to pests, doubts about ETs, and an overall reluctance toward IPM adoption.

Even in the face of these challenges, the implementation of IPM is feasible as successful cases are reported worldwide. The success of the Arizona IPM for Bemisia tabaci (Genn.) in cotton is a shining example of success. This program has reduced the use of insecticides by $70 \%$, providing savings of over US\$200 million in the first 14 years (Naranjo and Ellsworth 2009b). Another case of success is the cotton IPM program in Australia, which radically reduced the amount of insecticide applied per hectare (Wilson et al 2018).

In the state of Parana, Brazil, the lack of public extension professionals in the field has been compensated for by directly training the growers, who in fact are the on-farm decision makers. The National Rural Learning Service (SENAR) started to offer IPM training to growers who now are increasingly interested in soybean IPM, which is speeding up the adoption of this technology. The more deeply growers get involved in the process of decision-making, the more interested they are in this issue. Providing farmers and IPM professionals with 
training and information about cost-effective IPM tools and strategies, and thereby making them responsible for the IPM decisions on their farms, has proven to improve IPM adoption.

Not only should farmers be held responsible for IPM adoption but also the future of IPM depends upon IPM being embraced by farmers and consumers, as well as policy makers in a "win-win" relationship. Therefore, other measures such as IPM certification would help to differentiate soybean products on the market. Successful IPM programs worldwide have been associated with differentiated consumer products (e.g., eco-friendly or green products offered by various giant retailers), which helps to increase growers' profits and therefore encourages more growers to adopt IPM technology. In this context, it is important to understand that IPM is not a principle that strictly and uniformly applies to every situation, but rather a philosophy, influenced by different factors, that should guide IPM practitioners to use the most appropriate pest management tool available for each situation (Dara 2019). Only this balanced and adapted IPM recommendations to each farmers' reality is expected to support sustainable agricultural practices that combines business profitability for the soybean growers, affordability for consumers, and food security and environmental protection to the growing world population.

Acknowledgments The authors wish to thank "Empresa Brasileira de Pesquisa Agropecuária" (Embrapa) and the University of Nebraska Lincoln for all the support given to the authors and to the Brazilian Sponsor Agencies "Coordenação de Aperfeiçoamento de Pessoal de Nível Superior" (CAPES) and "Conselho Nacional de Desenvolvimento Científico e Tecnológico” (CNPq) for financial support and scholarships.

Author Contributions A.F. Bueno, A.R. Panizzi, P.M. Dourado, R.M. Pitta, and J. Gonçalves wrote the Brazilian soybean information. T.E. Hunt wrote the US information. All authors have read, edited, and approved the whole manuscript.

\section{References}

Alves TM, Macrae IV, Koch RL (2015) Soybean aphid (Hemiptera: Aphididae) affects soybean spectral reflectance. J Econ Entomol 108:2655-2664

Anderson PA, Pezzini DT, Bueno NM, DiFonzo CD, Finke DL, Hunt TE, Knodel JJ, Krupke CH, McCornack BP, Philips CR, Varenhorst AJ, Wright RJ, Koch RL (2020) Parasitism of adult Pentatomidae by Tachinidae in soybean in the North Central Region of the United States. J Insect Sci 2O(3):1-4. https://doi. org/10.1093/jisesa/ieaa030 
Bahlai CA, van derWerf W, O'Neal M, Hemerik L, Landis DA (2015) Shifts in dynamic regime of an invasive lady beetle are linked to the invasion and insecticidal management of its prey. Ecol Appl 25:1807-1818

Bajwa WI, Coop L, Kogan M (2003) Integrated pest management (IPM) and internet-based information delivery systems. Neotrop Entomol 32:373-383

Bastidas AM, Setiyono TD, Dobermann A, Cassman KG, Elmore RW, Graef GL, Specht JE (2008) Soybean sowing date: the vegetative, reproductive, and agronomic impacts. Crop Sci 48(2):727-740. https://doi.org/10.2135/ cropsci2006.05.0292

Batistela JM, Bueno AF, Nishikawa MAN, Bueno RCOF, Hidalgo G, Silva L, Corbo E, Silva RB (2012) Re-evaluation of leaf-lamina consumer thresholds for IPM decision in short-season soybeans using artificial defoliation. Crop Prot 32:7-11

Bernardi O, Malvestiti GS, Dourado PM, Oliveira WS, Martinelli S, Berger GU, Head GP, Omoto C (2012) Assessment of the high-dose concept and level of control provided by MON 87701 x MON 89788 soybean against Anticarsia gemmatalis and Pseudoplusia includens (Lepidoptera: Noctuidae) in Brazil. Pest Manag Sci 68(7):1083-1091

Bernardi O, Dourado PM, Carvalho RA, Martinelli S, Berger GU, Head GP, Omoto C (2014) High levels of biological activity of Cry1Ac protein expressed on MON $87701 \times$ MON 89788 soybean against Heliothis virescens (Lepidoptera:Noctuidae). Pest Manag Sci. https://doi.org/10.1002/ps.3581

Board JE, Maka V, Price R, Knight D, Baur ME (2007) Development of vegetation indices for identifying insect infestations in soybean. Agron J 99:650-656

Borges M, Schmidt FGV, Sujii ER, Medeiros MA, Mori K, Zarbin PHG, Ferreira JTB (1998) Field responses of stink bugs to the natural and synthetic pheromone of the Neotropical brown stink bug, Euschistus heros, (Heteroptera: Pentatomidae). Physiol Entomol 23:202-207

Brookes G, Barfoot P (2013) The global income and production effects of genetically modified (GM) crops 1996-2011. GM Crops Food 1:74-83. https:// doi.org/10.4161/gmcr.24176

Brookes G, Barfoot P (2016) GM crops: global socio-economic and environmental impacts 1996-2014. PG Economics Ltd, Dorchester, p 198

Brosius TR, Higley LG, Hunt TE (2007) Population dynamics of soybean aphid and biotic mortality at the edge of its range. J Econ Entomol 100:1268-1275. https://doi.org/10.1093/jee/100.4.1268

Bueno AF, Corrêa-Ferreira BS, Bueno RCOF (2010) Controle de pragas apenas com o MIP. A Granja 733:76-78

Bueno AF, Batistela MJ, Bueno RCOF, França-Neto JB, Nishikawa MAN, Filho AL (2011) Effects of integrated pest management, biological control and prophylactic use of insecticides on the management and sustainability of soybean. Crop Prot 30:937-945

Bueno AF, Paula-Moraes SV, Gazzoni DL, Pomari AF (2013) Economic thresholds in soybean-integrated pest management: old concepts, current adoption, and adequacy. Neotrop Entomol 42:439-447 
Bueno AF, Bortolotto OC, Pomari-Fernandes A, França-Neto JB (2015) Assessment of a more conservative stink bug economic threshold for managing stink bugs in Brazilian soybean production. Crop Prot 71: 132-137

Bueno AF, Hayashida R, Justus CM, Menezes Junior AO, Pasini A (2018) Produtividade e qualidade de grãos de soja submetidos a diferentes intensidades de injúria nas vagens. In: CONGRESSO BRASILEIRO DE SOJA, 8, 2018, Goiânia. Inovação, tecnologias digitais e sustentabilidade da soja: anais. Brasília, Embrapa, pp 147-149

Carmo EL, Bueno AF, Bueno RCOF (2010) Pesticide selectivity for the insect egg parasitoid Telenomus remus. BioControl 55:455-464

Carrière Y, Ellers-Kirk C, Sisterson M, Antilla L, Whitlow M, Dennehy TJ, Tabashnik BE (2003) Long-term regional suppression of pink bollworm by Bacillus thuringiensis cotton. Proc Natl Acad Sci U S A 100(4):1519-1523. https://doi.org/10.1073/pnas.0436708100

Carrière Y, Fabrick JA, Tabashnik BE (2016) Can pyramids and seed mixtures delay resistance to Bt crops? Trends Biotechnol 34:291-302. https://doi. org/10.1016/j.tibtech.2015.12.011

Carter J (1979) Integrated pest management memorandum from the president. The American Presidency Project

Castle S, Naranjo SE (2009) Sampling plans, selective insecticides and sustainability: the case for IPM as 'informed pest management'. Pest Manag Sci 65:1321-1328

Cattelan AJ, Dall'Agnol A (2018) The rapid soybean growth in Brazil. OCL 25(1):D102. https://doi.org/10.1051/ocl/2017058

Companhia Nacional de Abastecimento - CONAB (2017) Acompanhamento da safra brasileira de grãos. Safra 2016/17, $\mathrm{n}^{\circ} 11$ - Décimo primeiro levantamento. Agosto 2017. http://www.conab.gov.br/OlalaCMS/uploads/ arquivos/17 $08 \quad 101127 \quad 12$ boletim graos agosto 2017.pdf Accessed 30 Out 2017

Companhia Nacional de Abastecimento - CONAB (2019) Acompanhamento da safra brasileira de grãos. Safra 2018/19, $\mathrm{n}^{\circ} 12$ - Décimo segundo levantamento. Setembro 2019. file:///C:/Users/hp/Downloads/BoletimZGraosZsetembroZZresumoZ2019.pdf Accessed 02 Fev 2019

Conte O, Oliveira FT, Harger N, Corrêa-Ferreira BS (2014) Resultados do Manejo Integrado de Pragas da Soja na safra 2013/14 no Paraná. Londrina, EMBRAPACNPSo, EMBRAPA-CNPSo, (Documentos 356), p 56

Conte O, Oliveira FT, Harger N, Corrêa-Ferreira BS, Roggia S (2015) Resultados do Manejo Integrado de Pragas da Soja na safra 2014/15 no Paraná. Londrina, EMBRAPA-CNPSo, EMBRAPA-CNPSo, (Documentos 361), p 6o

Conte O, Oliveira FT, Harger N, Corrêa-Ferreira BS, Roggia S, Prando AM, Seratto CD (2016) Resultados do Manejo Integrado de Pragas da Soja na safra 2015/16 no Paraná. Londrina, EMBRAPA-CNPSo, (Documentos 375), p 59

Conte O, Oliveira FT, Harger N, Corrêa-Ferreira BS, Roggia S, Prando AM, Seratto CD (2017) Resultados do Manejo Integrado de Pragas da Soja na safra 2016/17 no Paraná. Londrina, EMBRAPA-CNPSo, (Documentos 394), p 70 
Conte O, Oliveira FT, Harger N, Corrêa-Ferreira BS, Roggia S, Prando AM, Seratto CD (2018) Resultados do Manejo Integrado de Pragas da Soja na safra 2017/18 no Paraná. Londrina, EMBRAPA-CNPSo, (Documentos 402), p 66

Conte O, Oliveira FT, Harger N, Corrêa-Ferreira BS, Roggia S, Prando AM, Possmai EJ, Reis EA Marx EF (2019) Resultados do Manejo Integrado de Pragas da Soja na safra 2018/19 no Paraná. Embrapa Soja, Londrina, (Documentos 416), p 63

Corrêa-Ferreira BS, Alexandre TM, Pellizzaro EC, Moscardi F, Bueno AF (2010) Práticas de manejo de pragas utilizadas na soja e seu impacto sobre a cultura. Embrapa Soja, Londrina, (Circular Técnica 78), p 15

Cumming GS, Spiesman BJ (2006) Regional problems need integrated solutions: pest management and conservation biology in agroecosystems. Biol Conserv 3:533-543

Dara SK (2019) The new integrated pest management paradigm for the modern age. J Integr Pest Manag 10:1-9. https://doi.org/10.1093/jipm/pmzo10

De Long DM (1932) Some problems encountered in the estimation of insect populations by the sweeping method. Ann Entomol Soc Am 25: 13-17

Desneux N, O'Neil RJ, Yoo HJS (2006) Suppression of population growth of the soybean aphid, Aphis glycines Matsumura, by predators: the identification of a key predator and the effects of prey dispersion, predator abundance, and temperature. Environ Entomol 35:1342- 1349

Diaz-Montano J, Reese JC, Schapaugh WT, Campbell LR (2006) Characterization of antibiosis and antixenosis to the soybean aphid (Hemiptera: Aphididae) in several soybean genotypes. J Econ Entomol 99:1884-1889

Dively GP, Venugopal PD, Bean D, Whalen J, Holmstrom K, Kuhar TP, Doughty HB, Patton T, Cissel W, Hutchison WD (2018) Regional pest suppression associated with widespread Bt maize adoption benefits vegetable growers. Proc Natl Acad Sci U S A 115(13):3320-3325

Douglas MR, Tooker JF (2015) Large-scale deployment of seed treatments has driven rapid increase in use of neonicotinoid insecticides and preemptive pest management in US field crops. Environ Sci Technol 49:5088-5097

Dourado PM, Bacalhau FB, Amado D, Carvalho RA, Martinelli S, Head GP, Omoto C (2016) High susceptibility to Cry1Ac and low resistance allele frequency reduce the risk of resistance of Helicoverpa armigera to Bt soybean in Brazil. PLoS One 1:e0161388. https://doi.org/10.1371/journal.pone.0161388

Ehler LE (2006) Integrated pest management (IPM): definition, historical development and implementation, and the other IPM. Pest Manag Sci 62:787-789

Elbert A, Haas M, Springer B, Thielert W, Nauen, R (2008) Applied aspects of neonicotinoid uses in crop protection. Pest Manag Sci 64: 1099-1105. https:// doi.org/10.1002/ps.1616

Elliot NC, Backoulou GF, Brewer MJ, Giles KL (2015) Ndvi to detect sugarcane aphid injury to grain sorghum. J Econ Entomol 108:1452-1455

Ellsworth PC, Fournier A, Frisvold G, Naranjo SE (2017) Chronicling the socioeconomic impact of integrating biological control, technology, and knowledge 
over 25 years of IPM in Arizona. In: Mason PG, Gillespie DR, Vincent (eds) Proceedings of the 5 th international symposium on biological control of arthropods. Langkawi, Malaysia, pp 214-216

FAOstat (2019) "Food and agriculture organization of the United Nations." Statistical database

Farias JR, Andow DA, Horikoshi RJ, Sorgatto RJ, Fresia P, dos Santos AC, Omoto C (2014) Field-evolved resistance to Cry1F maize by Spodoptera frugiperda (Lepidoptera: Noctuidae) in Brazil. Crop Prot 64:150-158

Fuxa JR, Richter AR (1999) Classical biological control in an ephemeral crop habitat with Anticarsia gemmatalis nucleopolyhedrovirus. BioControl 44:405-421

Gardiner MM, Landis DA, Gratton C, DiFonzo CD, O'Neal M, Chacon JM, Wayo MT, Schmidt NP, Mueller EE, Heimpel GE (2009) Landscape diversity enhances biological control of an introduced crop pest in the north-central USA. Ecol Appl 19:143-154

Gaspar AP, Marburger DA, Mourtzinis S, Conley SP (2014) Soybean seed yield response to multiple seed treatment components across diverse environments. Agron J 106:1955-1962

Giesler LJ, Ghabrial SA, Hunt TE, Hill JH (2002) Bean pod mottle virus: a threat to U.S. soybean production. Plant Disease 1280-1289

Godoy CV, Bueno AF, Gazziero Dionisio LP (2015) Brazilian soybean pest management and threats to its sustainability. Outlooks Pest Manage 26:113117. https://doi.org/10.1564/v26 jun 06

Green JM, Owen MDK (2011) Herbicide-resistant crops: utilities and limitations for herbicide-resistant weed management. J Agric Food Chem 59:5819-5829

Greene JK, Davis JA (2015) Stink bugs. In: Hartman GL, Rupe JC, Sikora EJ, Domier LL, Davis JA, Steffey KL (eds) Compendium of soybean diseases and pests, 5th edn. APS Press, St. Paul, pp 146-149

Hammond RB (2006) Soybean insect IPM. In: Radcliffe EB, Hutchison WD, Cancelado RE (eds) Radcliffe's IPM world textbook, https://ipmworld.umn.edu , University of Minnesota, St. Paul, MN, USA

Hesler LS, Dashiell KE, Lundgren JG (2007) Characterization of resistance to Aphis glycines in soybean accessions. Euphytica 154:91-99

Hesler SL, Allen CK, Luttrell RG, Sappington TW, Papiernik SK (2018) Earlyseason pests of soybean in the United States and factors that affect their risk of infestation. J Integr Pest Manag 9:19. https://doi.org/10.1093/jipm/pmxo28

Higley LG, Hammond RB (1994) Seedcorn maggot. In: Higley LG, Boethel DJ (eds) Handbook of soybean insect pests. Entomol. Soc. Am, Lantham, pp 77-79

Higley LG, Pedigo LP (1996) The EIL concept. In: Higley LG, Pedigo LP (eds) Economic threshold for integrated pest management. University of Nebraska Press, Lincoln, pp 9-21

Higley LG, Peterson RKD (1996) The biological basis of the EIL. In: Higley LG, Pedigo LP (eds) Economic threshold for integrated pest management. University of Nebraska Press, Lincoln, pp 22-40 
Hill CB, Li Y, Hartman GL (2004) Resistance to the soybean aphid in soybean germplasm. Crop Sci 44:98-106

Hill CB, Crull L, Herman T, Voegtlin DJ, Hartman GL (2010) A new soybean aphid (Hemiptera: Aphididae) biotype identified. J Econ Entomol 103:509-515

Hodgson EW, Burkness EC, Hutchison WD, Ragsdale DW (2004) Enumerative and binomial sequential sampling plans for soybean aphid (Homoptera: Aphididae) in soybean. J Econ Entomol 97:2127-2136

Hodgson EW, McCornack BP, Koch KA, Ragsdale DW, Johnson KD, O’Neal ME, Cullen EM, Kraiss HJ, DiFonzo CD, Behnken LM (2007) Field validation of speed scouting for soybean aphid. Online Crop Manag. https://doi.org/10.1094/ CM-2007-0511-01-RS

Hodgson EW, McCornack BP, Tilmon K, Knodel JJ (2012) Management recommendations for soybean aphid (Hemiptera: Aphididae) in the United States. J Integr Pest Manag 3:1-10

Huffman WE, Evenson RE (2006) Science for agriculture: a long-term perspective. Blackwell Publishing, Ames, p 314

Huis AV, Meerman F (1997) Can we make IPM work for resource-poor farmers in sub-Saharan Africa? Int J Pest Manage 43:313-320

Hunt TE, Higley LG, Witkowski JF (1994) Soybean growth and yield after bean leaf beetle injury to seedlings. Agron J 86(1):140-146

Hunt TE, Higley LG, Witkowski JF (1995) Bean leaf beetle injury to seedling soybean: consumption, effects of leaf expansion and economic injury levels. Agron J 87(2):183-188

Hurley T, Mitchell P (2017) Value of neonicotinoid seed treatments to US soybean farmers. Pest Manag Sci 73(1):102-112

Hutchison WD, Burkness EC, Mitchell PD, Moon RD, Leslie TW, Fleischer SJ, Abrahamson M, Hamilton KL, Steffey KL, Gray ME, Hellmich RL,

Kaster LV, Hunt TE, Wright RJ, Pecinovsky K, Rabaey TL, Flood BR, Raun ES (2010) Area-wide suppression of European corn borer with Bt maize reaps savings to non-Bt maize growers. Science 330(6001): 222-225. https://doi. org/10.1126/science.1190242

Kim KS, Hill CB, Hartman GL, Mian MAR, Diers BW (2008) Discovery of soybean aphid biotypes. Crop Sci 48:923-928

Koch RL, Potter BD, Glogoza PA, Hodgson EW, Krupke CH, Tooker JF, DiFonzo CD, Michel AP, Tilmon KJ, Prochaska TJ, Knodel JJ, Wright RJ,

Hunt TE, Jensen B, Varenhorst AJ, McCornack BP, Estes KA, Spencer J (2016) Biology and economics of recommendations for insecticide-based management of soybean aphid. Plant Health Progress 17(4): 265-269. https://doi. org/10.1094/PHP-RV-16-0061

Kogan M (1998) Integrated pest management: historical perspectives and contemporary developments. Annu Rev Entomol 43:243-270

Kogan M, Turnipseed SG (1987) Ecology and management of soybean arthropods. Annu Rev Entomol 32:507-538 
Kogan M, Turnipseed SG, Shepard M, Oliveira EB, Borgo A (1977) Pilot insect pest management program for soybean in southern Brazil. J Econ Entomol 70:659-663

Krell RK, Fisher ML, Steffey LL (2016) A proposal for public and private partnership in extension. J Integr Pest Manag 7:1-10

Krupke CH, Alford AM, Cullen EM, Hodgson EW, Knodel JJ, McCornack B, Potter BD, Spigler MI, Tilmon K, Welch K (2017) Assessing the value and pest management window provided by neonicotinoid seed treatments for management of soybean aphid (Aphis glycines Matsumura) in the Upper Midwestern United States. Pest Manag Sci 73:2184- 2193. https://doi. org/10.1002/ps.4602

Marcuzzo FFN, Rocha HM, Melo DCR (2011) Mapeamento da precipitação pluviométrica no bioma cerrado do estado do Mato Grosso. B Goiano Geogr 31:83-97

Meissle M, Mouron P, Musa T, Bigler F, Pons X, Vasileiadis VP, Otto S, Antichi D, Kiss J, Pálinkás Z, Dorner Z, van der Weide R, Groten J, Czembor E, Adamczyk J, Thibord JB, Melander B, Cordsen Nielsen G, Poulsen RT, Zimmermann O, Vershwele A, Oldenburg E (2010) Pest, pesticides use and alternative options in European maize production: current status and future prospects. J Appl Entomol 134:357-375

Mourtzinis S, Krupke CH, Esker PD, Varenhorst A, Arneson NJ, Bradley CA, Byrne AM, Chilvers MI, Giesler LJ, Herbert A, Kandel YR, Kazula MJ, Hunt C, Lindsey LE, Malone S, Mueller DS, Naeve S, Nafziger E, Reisig DD, Ross WJ, Rossman DR, Taylor S, Conley SP (2019)

Neonicotinoid seed treatments of soybean provide negligible benefits to US farmers. Sci Rep 9:11207. https://doi.org/10.1038/s41598-019-47442-8

Nansen C, Zhang A, Yan G (2014) Use of variogram analysis to classify field peas with and without internal defects caused by weevil infestation. J Food Eng 123:17-22

Naranjo SE, Ellsworth PC (2009a) Fifty years of the integrated control concept: moving the model and implementation forward in Arizona. Pest Manag Sci 65:1267-1286

Naranjo SE, Ellsworth PC (2009b) The contribution of conservation biological control to integrated control of Bemisia tabaci in cotton. Biol Control 51(3):458-470. https://doi.org/10.1016/j.biocontrol.2009.08.006

Nixon R (1972) Special message to congress outlining the 1972 environmental program. The American Presidency Project

Nowierski RM, Meyer HJ (2008) Establishing inter-agency, multidisciplinary programmes. In: Koul O, Cuperus GW, Elliott N (eds) Area-wide pest management: theory and implementation. CAB International, Oxfordshire, pp 34-58

Oerke EC (2006) Crop losses to pests. J Agric Sci 144:31-43

Oerke EC, Dehne HW (2004) Safeguarding production - losses in major crops and the role of crop protection. Crop Prot 23:275-285 
Omoto C, Bernardi O, Salmeron E, Sorgatto RJ, Dourado PM, Crivellari A, Carvalho RA, Willse A, Martinelli S, Head GP (2016) Field-evolved resistance to Cry1Ab maize by Spodoptera frugiperda in Brazil. Pest Manag Sci 72(9):1727-1736. https://doi.org/10.1002/ps.4201

Panizzi AR (1980) Manejo de pragas: situação atual e perspectivas futuras. In: Anais do VI Congresso Brasileiro de Entomologia, Campinas, pp 303-322

Panizzi AR (2013) History and contemporary perspectives of the integrated pest management of soybean in Brazil. Neotrop Entomol 42:119- 127

Panizzi AR, Corrêa BS, Newman GG, Turnipseed SG (1977a) Efeito de inseticidas na população das principais pragas da soja. An Soc Entomol Brasil 6:264-275

Panizzi AR, Corrêa BS, Gazzoni DL, Oliveira EB, Newman GG, Turnipseed SG (1977b) Insetos da soja no Brasil Embrapa, CNPSo, Londrina, PR. Bol Téc 1:20

Papiernik SK, Sappington TW, Luttrell RG, Hesler LS, Allen KC (2018) Overview: risk factors and historic levels of pressure from insect pests of seedling corn, cotton, soybean, and wheat in the United States. J Integr Pest Manag 9:1-18

Pedigo LP, Hutchins SSH, Higley LG (1986) Economic injury levels in theory and practice. Annu Rev Entomol 31:341-368

Peterson RKD, Higley LG (2002) Economic decision levels. In: Pimentel D (ed) Encyclopedia of pest management. Marcel Dekker, New York, pp 228-238

Peterson RKD, Hunt TE (2003) The probabilistic economic injury level: incorporating uncertainty into pest management decision-making. J Econ Entomol 96:536-543

Peterson RKD, Higley LG, Pedigo LP (2018) Whatever happened to IPM? Am Entomol 64:146-150

Pezzini DT, DiFonzo CD, Finke DL, Hunt TE, Knodel JJ, Krupke CH, McCornack B, Michel AP, Varenhorst AJ, Wright RJ, Koch RL (2019a) Community composition, abundance and temporal dynamics of stink bugs (Hemiptera: Pentatomidae) in soybean in the North Central Region of the U.S. J Econ Entomol 112(4):17221731. https://doi.org/10.1093/jee/tozogg

Pezzini DT, DiFonzo CD, Finke DL, Hunt TE, Knodel JJ, Krupke CH, McCornack B, Michel AP, Moon RD, Philips CR, Varenhorst AJ, Wright RJ, Koch RL (2019b) Spatial patterns and sequential sampling plans for stink bugs (Hemiptera: Pentatomidae) in soybean in the North Central Region of the U.S. J Econ Entomol 112(4):1732-1740. https://doi.org/10.1093/jee/toz10o

Pierson LM, Heng-Moss TM, Hunt TE, Reese JC (2010) Categorizing the resistance of soybean genotypes to the soybean aphid (Hemiptera: Aphididae). J Econ Entomol 103:1405-1411

Pires CSS, Sujii ER, Schmidt FGV, Santos HM, Pais JSO, Borges M (2000) Potencial de utilização de armadilhas iscadas com o feromônio sexual do percevejo marrom, Euschistus heros: uma nova metodologia para o monitoramento populacional de percevejos praga da soja. Embrapa-Cenargen, Brasília,(Circular Técnica 7), p 24

Potamitis I, Rigakis I (2015) Novel noise-robust optoacoustic sensors to identify insects through wingbeats. IEEE Sensors J 15:4621-4631 
Potamitis I, Rigakis I, Fysarakis K (2015) Insect biometrics: optoacoustic signal processing and its applications to remote monitoring of McPhail type traps. PLoS One 10:01-33

Ragsdale DW, Voegtlin DJ, O'Neil RJ (2004) Soybean aphid biology in North America. Ann Entomol Soc Am 97:204-208

Ragsdale DW, McCornack BP, Venette RC, Potter BD, MacRae IV, Hodgson EW, O'Neal ME, Johnson KD, O'Neil RJ, DiFonzo CD, Hunt TE, Glogoza PA, Cullen EM (2007) Economic threshold for soybean aphid. J Econ Entomol 100:1258-1267

Ragsdale DW, Landis DA, Brodeur J, Heimpel GE, Desneux N (2011) Ecology and management of the soybean aphid in North America. Annu Rev Entomol 56:375-399

Romeis J, Naranjo SE, Meissle M, Shelton AM (2018) Genetically engineered crops help support conservation biological control. Biol Control 130:136-154. https:// doi.org/10.1016/j.biocontrol.2018.10.001

Sappington T (2014) Emerging issues in integrated pest management implementation and adoption in the North Central USA. In: Peshin R, Pimentel D (eds) Integrated Pest management. Springer, Dordrecht, pp 65-97. https:// doi.org/10.1007/978-94-007-7802-3_4

Schmidt FGV, Pires CSS, Sujii ER, Borges M, Pantaleão DC, Lacerda ALM, Azevedo VCR (2003) Comportamento e captura das fêmeas de Euschistus heros em armadilhas iscadas com feromônio sexual. Embrapa-Cenargen, Brasília, (Comunicado Técnico 93), $4 \mathrm{p}$

Smelser RB, Pedigo LP (1992) Soybean seed yield and quality reduction by bean leaf beetle (Coleoptera: Chrysomelidae) pod injury. J Econ Entomol 85:2399-2403

Song F, Swinton SM (2009) Returns to integrated pest management research and outreach for soybean aphid. J Econ Entomol 102:2116-2125

Steffey KL (2015) Insects and their management. In: Hartman GL, Rupe JC, Sikora EJ, Domier LL, Davis JA, Steffey KL (eds) Compendium of soybean diseases and pests, 5th edn. APS Press, St. Paul, pp 136-137

Stern VM, Smith RF, Van Den Bosch R, Hagen KS (1959) The integrated control concept. Hilgardia 29:81-101

Turnipseed SG (1974) Manejo das pragas da soja no Sul do Brasil. Trigo-Soja 1:4-7

United States Department of Agriculture - USDA (2020) Oilseeds: World Markets and Trade. https://usda.library.cornell.edu/usda-esmis/files/tx31qh68h/ vt151125j/44558w98r/oilseeds.pdf . Accessed o2 Fev 2020

USDA NASS (USDA, National Agricultural Statistics Service) (2018) Crop production. http://www.nass.usda.gov/ . Accessed 5 July 2019

USGS (United States Geological Survey) (2018) National Water-Quality Assessment (NAWQA) Project Pesticide Use Maps, http://water.usgs.gov/ nawqa/pnsp/usage/maps . Accessed o2 Dec 2019

Varella AC, Menezes-Netto AC, de Souza Alonso JD, Caixeta DF, Peterson RKD, Fernandes OA (2015) Mortality dynamics of Spodoptera frugiperda (Lepidoptera: Noctuidae) immatures in maize. PLoS One 10:1-12 
Wan P, Huang Y, Tabashnik BE, Huang M, Wu K (2012) The halo effect: suppression of pink bollworm on non-Bt cotton by Bt cotton in China. PLoS One 7(7):e42004. https://doi.org/10.1371/journal.pone.0042004

Wang SL (2014) Cooperative extension system: trend and economic impacts on U.S. agriculture. Choices 1:1-8

Wang SL, Ball E, Fulginiti L, Plastina A (2012) Accounting for the impacts of public research, R\&D spill-ins, extension, and roads in U.S. agricultural productivity growth. In: Fuglie KO, Wang SL, Ball VE (eds) Agricultural productivity: an international perspective. Cabi, Cambridge, pp 13-31

Way MO (1994) Status of soybean insect pests in the USA. In: Higley LG, Boethel DJ (eds) Handbook of soybean insect pests. Entomol Soc Am, Lanham, pp 15-16

Wen C, Wu D, Hu H, Pan W (2015) Pose estimation-dependent identification method for field moth images using deep learning architecture. Biosyst Eng 136:117-128

Williams RN, Panaia JR, Moscardi F, Sichmann W, Allen GE, Greene GL, Lasca DHC (1973) Principais pragas da soja no estado de São Paulo: reconhecimento, métodos de levantamento e melhor época de controle. Secr Agric, CATI, p 18

Wilson LJ, Whitehouse MEA, Herron GA (2018) The management of insect pests in Australian cotton: an evolving story. Annu Rev Entomol 63(1):215-237 Soybean IPM Challenges 19

Witkowski JF, Echtenkamp GW (1996) Influence of planting date and insecticide on bean leaf beetle (Coleoptera: Chrysomelidae) abundance and damage in Nebraska. J Econ Entomol 89:189-196

Wu KM, Lu YH, Feng HQ, Jiang YY, Zhao JZ (2008) Suppression of cotton bollworm in multiple crops in China in areas with Bt toxin-containing cotton. Science 321(5896):1676-1678. https://doi.org/10.1126/science.1160550

Yano SAC, Specht A, Moscardi F, Carvalho RA, Dourado PM, Martinelli S, Head GP, Sosa-Gómez D (2016) High susceptibility and low resistance allele frequency of Chrysodeixis includens (Lepidoptera: Noctuidae) field populations to Cry1Ac in Brazil. Pest Manag Sci 72(8):1578-1584

Zalucki MP, Adamson D, Furlong MJ (2009) The future of IPM: whither or wither? Aust J Entomol 48:85-96. https://doi.org/10.1111/j.1440-6055.2009.00690.x

Zanon A, Streck NA, Richter GL, Becker CC, Da Rocha TSM, Cera JC, Winck JEM, Cardoso ÂP, Tagliapietra EL, Weber PS (2015) Contribuição das ramificações e a evolução do índice de área foliar em cultivares modernas de soja. Bragantia. 74:279-29o. https://doi.org/10.1590/1678-4499.0463.

Zhang W, Lu Y, van der Werf W, Huang J, Wu F, Zhou K, Deng X, Jiang Y, Wu K, Rosegrant MW (2018) Multidecadal, county-level analysis of the effects of land use, Bt cotton, and weather on cotton pests in China. Proc Natl Acad Sci U S A 115(33):E7700-E7709. https://doi.org/10.7910/DVN/QVBQQQ 